\title{
Issues of Attraction and Retention of Nurses: Job Control, Time and Work-Family Issues
}

\author{
Diane-Gabrielle Tremblay* \\ School of Administrative Sciences, University of Québec, Téluq, Montréal \\ Email: *dgtrembl@teluq.ca
}

How to cite this paper: Tremblay, D.-G. (2021). Issues of Attraction and Retention of Nurses: Job Control, Time and Work-Family Issues. Journal of Human Resource and Sustainability Studies, 9, 524-540. https://doi.org/10.4236/jhrss.2021.94033

Received: August 14, 2021

Accepted: November 13, 2021

Published: November 16, 2021

Copyright $\odot 2021$ by author(s) and Scientific Research Publishing Inc. This work is licensed under the Creative Commons Attribution International License (CC BY 4.0).

http://creativecommons.org/licenses/by/4.0/

\begin{abstract}
Over the years there have been many challenges in attracting and retaining various workers, especially in the health sector, and for nurses in particular. Literature has often mentioned the increased difficulties in attracting and retaining young nurses in particular and this increases labour shortage due to the demographic evolution and also to retirement of many nurses. With the aging of population, we see an increase in demand for health services, which makes the labor shortage even more preoccupying. Two main issues have been put forward a few years ago in order to try to explain the difficulty in attracting and retaining nurses: work organization and Lean Management, in particular job control and work-family balance issues. We conducted a research in Canada (Québec) with an online questionnaire sent to a sample of nurses. The article presents the result in the form of descriptive statistics. In this article, we address these challenges and identify the elements on which the Health Department and hospitals could act in order to increase the number of nurses, and more specifically to attract and retain more. For this, two main issues are addressed in the literature that is firstly work-life issues, and second, work organization, including (lean) management and job control, which we discuss here. These results could also be useful for attraction and retention of other health personnel and also for managers facing labor shortages in other sectors.
\end{abstract}

\section{Keywords}

Work-Life, Work-Family, Attraction, Retention, Nurses, Job Control, Time

\section{Introduction}

Over the years there have been many challenges in attracting and retaining various workers, especially in the health sector, and for nurses in particular (Bélanger \& Marois, 2015; Tremblay, 2014a). Literature has often mentioned the in- 
creased difficulties in attracting and retaining young nurses in particular (Côté, 2016; Côté et al. 2014) and this increases labour shortage related to the demographic evolution (Bélanger et Marois, 2015), and also to retirement of many nurses (Farges et Tremblay, 2016). With the aging of population, we see an increase in demand for health services, which makes the labor shortage even more preoccupying. Two main issues had been put forward a few years ago in order to try to explain the difficulty in attracting and retaining nurses: work organization and lean management, in particular job control and work-family balance issues. In recent years, in Canada, work-family balance issues and job control or autonomy were often put forward as a main difficulty or resentment for nurses, pushing them to leave the profession early, as soon as 5 years after graduation (Tremblay, 2014a), early retirement remaining a challenge in many occupations and organizations searching for solutions to maintain their workers in employment (Mansour \& Tremblay, 2019, 2018a).

In some countries, these challenges have led to the adoption of lean management, some organizations consider they can find here solutions to increase the work done in the health and especially nursing sector (Tremblay, 2014b; Bourbonnais et al., 2000). Also, as in many other countries, aging in Québec (Canada) is important. The Health Department expects that in 2031, 15\% of the population will be 65 and over, and the number of 85 and over will double within 20 years from now. Also, the Health Dept. indicates that $48 \%$ of the population aged 15 and over has at least one chronic health issue. Therefore, the gap between public income and increase in health costs is increasing, calling for solutions to be found. This is why lean management sometimes is introduced in certain organizations (Bouville \& Trempe, 2015).

In this article, we will address these challenges and try to find the elements on which the Health Department and hospitals could act in order to increase the number of nurses, and more specifically to attract and retain more. For this, two main issues are addressed in the literature that is firstly work-life issues, and second, work organization, (lean) management and job control. This article presents the results of a research we conducted with online questionnaire on these issues, with nurses in Canada (Québec).

\subsection{Work-Life Issues and Attraction-Retention}

Work-family interface issues have been at the center of social debate in many industrialized nations over recent years (Tremblay, 2019; Poelmans, Greenhaus, \& Maestro, 2013; Allen, 2012), and this is the case for the nursing sector as well as others (Mansour \& Tremblay, 2018b, 2018d; Tremblay, 2014a). Work-family interface refers to the reciprocal influence of work on family and of family on word, and the tensions which this interface can create in terms of roles and lack of time, and stress due to these roles and time tensions (Poelmansl, Greenhaus, \& Maestro, 2013; Fiksenbaum, 2014). It is most certainly more important for the health sector than many others as it is a sector with a majority of women, and 
thus gender and work-family interface is an essential issue here (Nsaful et al., 2021; Tremblay, 2019). While the Canadian province of Québec is recognized for its family policy and good public support to work-life balance (Tremblay, 2014b, 2009, 2008), the challenges are still important at the organizational level. Indeed, this challenge of work-life interface has increased with demographic decline in many countries, but also in relation with the increased participation of women and increased number of dual-earner couples in the workforce, which also means that both partners are increasingly faced with this work-family issue. In this context, workers look for the support of their employers and managers (Fiksenbaum, 2014, Goh et al., 2015).

In the health sector as in others, especially those where workers are dealing with humans and not objects, work-life challenges are seen as having a major impact on employee well-being (Eby, Maher, \& Butts, 2010). Work-family measures thus have an impact on work engagement and professional stress, which can in turn have an impact on how nurses deal with their patients (Braunstein-Bercovitz, 2013). Organizational policies and measures to support workers with work-family reconciliation are thus crucial, but research has shown that it is not always sufficient, especially in sectors such as nursing or other organizations functioning $24-7$, as it is not always possible to benefit from flexible schedules or telework in such sectors (Tremblay, 2012). It is thus often a challenge to eliminate or even reduce the negative effects of work-family conflict on work attitudes and organizational performance and results (Fiksenbaum, 2014; Tremblay, 2014b). Some authors have also observed that the application of work-family measures depends on top management (Hammer et al., 2009) and over recent years, in Québec (Canada), nurses have often had to do overtime, and thus, work-family balance has been even more difficult to achieve. Other research has also indicated that gender can have an influence on work-family conflict and satisfaction of medical doctors (Nsaful et al., 2021) and this could also be the case for nurses and have an influence on attraction and retention.

Organizational culture can have an impact on work attitudes and results, and compulsory overtime and non-supportive organizational climate have surely had a negative impact on this culture, as well as work attitudes and results over recent years (Tremblay, 2014a; Kossek, Pichler, Bodner, \& Hammer, 2011; Allen, 2012; Mansour \& Tremblay, 2018b, 2018c, 2018d).

\subsection{Lean Management, Job Control and Autonomy}

Given the challenges in the health sector, work organization is often redesigned, as mentioned above. Recently, work reorganization has often been done in the form of what is called Lean Management.

As indicated in various documents, including Boudeau-Laforce (2014) and FIQ (2011), Lean Management aims at revising all labor processes and work tasks in order to make them more fluid and reduce time losses, increasing flexibility in response to demands, abolishing tasks which don't translate into value 
or income, all this being considered as ways to reduce costs. In some cases, while the objective is to reduce costs, and time for tasks, this translates into more stress, burnout and nurses' intention to leave the profession (Tremblay, 2014a; Lazzari \& Tremblay, 2016). Nurses' unions have criticized this application of Lean, indicating that when its objective is largely centered cost reduction, it does not offer a better quality of service, and actually leads to an "obsessive" culture of measuring, which again can run counter to better health services (FIQ, 2011: p. 10). There are also questions as concerns the usefulness and the validity of this management mode, as well as its tools and methods (FIQ 2011: p. 10). While there are critiques of this management mode, it has nevertheless been implemented in a good number of hospitals and health organizations, with variable results. This is what led us to look into this issue and particularly into the time constraints imposed for various tasks, which seem to generate the most dissatisfaction. Indeed, while nurses recognize that the process sometimes leads to improvements (for ex. in placing medical devices and equipment for them to be easy to find, and reduce time lost during processes), there are critiques; our research aimed to determine if these critiques to Lean Management (Parisot, 2014), were still valid a few years after the introduction of this management mode and to what extent they contribute to nurses' dissatisfaction.

This is important since this dissatisfaction can lead to leaving the profession or health sector, to early retirement, and to challenges in attraction and retention of nurses, while on the contrary hospitals and health organizations are keen to attract and retain nurses given the huge labor shortage observed over recent years. Labor shortage for nursing and other health workers surely require a revision of work organization, but the issue is how exactly to redesign tasks and work organization in order to attain simultaneously a better performance, but also quality of service (Bouville \& Trempe, 2015). It is in this context of labor shortage that some health organizations adopted Lean Management (Jancarik \& et Vermette, 2013), even if there have been critiques in Québec (FIQ, 2011) but also abroad (Boudou-Laforce, 2014; Parisot, 2014), as mentioned above. Reduction in resources and administrative overload seem to be at the center of critiques of the application of this method in the health sector (Parisot, 2014). As noted by Lorino (cited in Parisot, 2014), Doing "skinny" Lean goes counter to the real basic objectives of the Lean philosophy. Indeed, the Japanese vision of Lean tends to give more importance to the innovation aspect, and considers the workers at the center of the process as the experts of the work activity. Lorino indicates that when Taiichi Ohno (main recognized author of the Lean Method) suggested to do more with less, he was not thinking of increasing the output by reducing input but rather of creating more value with less workload, and less effort (Lorino, in Parisot, 2014). Lorino also considers we should return to the origins of the Lean philosophy, to its Japanese origin in fact and to complement it by taking into account needs and knowledge of workers and their representatives (Lorino, cited in Parisot, 2014). 
Unfortunately, in its application in the health sector, nurses and other health workers often have a negative view of Lean Management, considering it "as essentially a way of assimilating patients to clients, in the new terminology, and with a negative impact on other dimensions of performance such as working conditions, efficiency and quality of care" (Bouville \& Trempe, 2015: p. 265). Bouville and Trempe (2015) explain these observations by the fact that formal and informal organizational practices and actual work processes are ignored, which leads to perverse effects, mainly in the form of rationalizations.

Many health workers thus consider that Lean Management means mainly rationalization, work intensification, reduction of resources (personnel and other resources or means to do the work), all this translating into dissatisfaction and less well-being at work (Bouville \& Trempe, 2015) as well as a deterioration of the quality of care (Waring \& Bishop, 2010; Belorgey, 2011).

According to various authors writing on Lean (Bouville \& Trempe, 2015) and on Japanese management methods (Tremblay \& Rolland, 2019), the role of workers in the work process should be taken into account in order to avoid work intensification, which might be an obstacle to the attainment of performance objectives. The proactive role of workers should be favored, and their competencies, job control and decision-making capacities should be taken acknowledged, and rather increased than diminished (Malenfant et al., 2010), as was initially proposed in the Japanese model of innovation management (Tremblay \& Rolland, 2019).

Our research and article extend Lean Management as well as work-life literature in an important manner, in particular for the specific challenges encountered in the nursing sector, which have a major impact on attraction and retention of nurses. While much literature and media coverage in Québec over the recent years has stressed the negative impact of Lean Management, some nurses' unions have also put forward the negative impacts of these Lean and Six Sigma management practices, including the lack of autonomy and their tendency to reduce the human and professional dimensions of nursing work (FIQ, 2011). Other research has also indicated that work environment is an important factor for recruitment and retention of nurses (Oyetunde \& Ayeni, 2014), as well as job security and wage increases for their case.

As attraction and retention of nurses has become a crucial challenge, especially during and after the pandemic, and acknowledging the elements mentioned above concerning Lean Management and work-life interference, our research aimed to determine what are the main elements which are still an issue for nurses and present obstacles for their attraction and retention. The next sections will thus present the methodology of the research and then a first analysis of results from our research.

\section{Methodology}

The research used mixed methods in order to gather data, that is interviews and 
online quantitative questionnaire. The results presented here are derived from the quantitative survey of a little under 800 nurses, who responded to an online questionnaire in November-December 2020. The respondents were contacted through a sample of emails which we obtained from the professional order of nurses, of which all nurses need to be member in order to work as a nurse. We have also been conducting interviews with nurses over the last two years, but this qualitative part of the research is not covered here as the process of interviews is not yet complete; however, as we have started transcriptions, these interviews give us a better understanding of the issues at stake here, including nurses' views on work-family balance, work organization (including Lean management), job stability or insecurity for those who do not have permanent full time employment.

The questionnaire mainly asked questions on work-family balance measures (childcare, flexible hours, etc.), on their work organization, on the level of autonomy in decision making, as this was presented as an important issue in nurses' collective bargaining in Québec in 2019-20.

The survey link was sent by email, by a nurses' association to some 2000 nurses in Québec (Canadian province). The organization selected the emails in a random fashion out of their database of registered nurses in Québec. There were 792 usable questionnaires of which 602 were from nurses, and 190 were from nurses who also had some form or management or coordination function in their department or establishment. These nurses work in hospitals or in local clinics. Responses are generally based on a Likert scale in 5 points.

We conducted descriptive statistics analysis to identify the main issues and factors which could increase attraction and retention of nurses. This paper thus centers on the issue of work-family interference, lack of time (often related to Lean) and autonomy in decision making as these were put forward in literature and media coverage as the main source of discontent to explain the difficulty in attracting and retaining nurses over the last years, and even decade, and they appear important in our results.

\section{Results}

This paper presents a first exploration of this issue with descriptive statistics from this survey in order to answer the question as to whether work-family issues, job control or autonomy in decision making and time limits related to Lean management can be a source of discontent, and lead to difficulties in attraction and retention of nurses.

Results are presented in three sections, related to the three issues which appear important for nurses and which we thus wanted to investigate as sources of problems for attraction and retention: 1) autonomy in decision making; 2) work-family interference; 3-lack of time for execution of work (related to Lean Management in the literature and nurses' union documents (Parisot, 2014; Nogues \& Tremblay, 2019; FIQ, 2011). 


\subsection{Job Control and Autonomy}

As concerns job control and autonomy in decision making and in work, we observe, contrary to expectations in relation with the Lean literature, that the majority of nurses agree that their work gives them the opportunity to exert their personal initiative or judgement in their work (Table 1) Also, nurses indicate that their work gives them the opportunity to take decisions on their own, again, contrary to what can be expected with the application of Lean Management (Table 2). Finally, a majority also feels that their work gives them enough autonomy to take decisions (Table 3). On the basis of these results, which will be the object of more research in the future, it appears that autonomy and opportunity for decision making to not appear to be the main issue, at least according to these respondents, and contrarily to what could expected from the literature. Also, we note that nurses as well as chief nurses appear to have similar views on this issue, the percentages of agreement being essentially between $70 \%$ and $80 \%$ for both groups if we add the responses Agree and Totally agree.

\subsection{Work-Family Interference}

We now turn to the issue of work-family and work-life interference to see if this is more of an issue for nurses. As concerns work-family or work-life interference, we find more mixed results, although work-family interference seems often dominant. While there are often one fifth of respondents who are unsure (neither agree nor disagree), it appears that work does interfere with family activities, and responsibilities, although most respondents consider they find a way to take on their responsibilities, or at least respond that they do so.

Table 1. My work gives me the opportunity to exert my personal initiative or my judgment in execution of my work.

\begin{tabular}{|c|c|c|c|c|c|}
\hline & & & \multicolumn{2}{|c|}{ JobTitle } & \multirow{2}{*}{ Total } \\
\hline & & & Chief Nurse & Nurse & \\
\hline & & & 0.00 & 1.00 & \\
\hline \multirow{10}{*}{ AUTDM1 } & \multirow{2}{*}{ Totally disagree } & Number & 1 & 12 & 13 \\
\hline & & $\%$ in JobTitle & $0.5 \%$ & $2.0 \%$ & $1.6 \%$ \\
\hline & \multirow{2}{*}{ Disagree } & Number & 13 & 39 & 52 \\
\hline & & $\%$ in JobTitle & $6.8 \%$ & $6.5 \%$ & $6.6 \%$ \\
\hline & \multirow{2}{*}{$\begin{array}{l}\text { Neither agree } \\
\text { nor disagree }\end{array}$} & Number & 17 & 46 & 63 \\
\hline & & $\%$ in JobTitle & $8.9 \%$ & $7.6 \%$ & $8.0 \%$ \\
\hline & \multirow{2}{*}{ Agree } & Number & 80 & 329 & 409 \\
\hline & & $\%$ in JobTitle & $42.1 \%$ & $54.7 \%$ & $51.6 \%$ \\
\hline & \multirow{2}{*}{ Totally agree } & Number & 79 & 176 & 255 \\
\hline & & $\%$ in JobTitle & $41.6 \%$ & $29.2 \%$ & $32.2 \%$ \\
\hline \multirow{2}{*}{\multicolumn{2}{|c|}{ Total }} & Total & & 602 & 792 \\
\hline & & $\%$ in JobTitle & & $100.0 \%$ & $100.0 \%$ \\
\hline
\end{tabular}


Table 2. My work gives me the possibility to take many decisions on my own.

\begin{tabular}{|c|c|c|c|c|c|}
\hline & & & \multicolumn{2}{|c|}{ JobTitle } & \multirow{2}{*}{ Total } \\
\hline & & & Chief nurse & Nurse & \\
\hline \multirow{12}{*}{ AUTDM2 } & & Number & 5 & 16 & 21 \\
\hline & & $\%$ in JobTitle & $2.6 \%$ & $2.7 \%$ & $2.7 \%$ \\
\hline & \multirow{2}{*}{ Disagree } & Number & 22 & 81 & 103 \\
\hline & & $\%$ in JobTitle & $11.6 \%$ & $13.5 \%$ & $13.0 \%$ \\
\hline & \multirow{2}{*}{$\begin{array}{c}\text { Neither agree nor } \\
\text { disagree }\end{array}$} & Number & 14 & 90 & 104 \\
\hline & & $\%$ in JobTitle & $7.4 \%$ & $15.0 \%$ & $13.1 \%$ \\
\hline & \multirow{2}{*}{ Agree } & Number & 84 & 277 & 361 \\
\hline & & \% in JobTitle & $44.2 \%$ & $46.0 \%$ & $45.6 \%$ \\
\hline & \multirow{2}{*}{ Totally agree } & Number & 65 & 138 & 203 \\
\hline & & $\%$ in JobTitle & $34.2 \%$ & $22.9 \%$ & $25.6 \%$ \\
\hline & \multirow{2}{*}{ Total } & Total & 190 & 602 & 792 \\
\hline & & $\%$ in JobTitle & $100 \%$ & $100.0 \%$ & $100.0 \%$ \\
\hline
\end{tabular}

Table 3. My work gives me a lot of autonomy to take decisions.

\begin{tabular}{|c|c|c|c|c|c|}
\hline & & & \multicolumn{2}{|c|}{ JobTitle } & \multirow{2}{*}{ Total } \\
\hline & & & Chief nurse & Nurse & \\
\hline \multirow{10}{*}{ AUTDM3 } & \multirow{2}{*}{ Totally disagree } & Number & 4 & 22 & 26 \\
\hline & & $\%$ in JobTitle & $2.1 \%$ & $3.7 \%$ & $3.3 \%$ \\
\hline & \multirow{2}{*}{ Disagree } & Number & 24 & 88 & 112 \\
\hline & & $\%$ in JobTitle & $12.6 \%$ & $14.6 \%$ & $14.1 \%$ \\
\hline & \multirow{2}{*}{$\begin{array}{c}\text { Neither agree nor } \\
\text { disagree }\end{array}$} & Number & 30 & 124 & 154 \\
\hline & & $\%$ in JobTitle & $15.8 \%$ & $20.6 \%$ & $19.4 \%$ \\
\hline & \multirow{2}{*}{ Agree } & Number & 83 & 256 & 339 \\
\hline & & $\%$ in JobTitle & $43.7 \%$ & $42.5 \%$ & $42.8 \%$ \\
\hline & \multirow{2}{*}{ Totally agree } & Number & 49 & 112 & 161 \\
\hline & & $\%$ in JobTitle & $25.8 \%$ & $18.6 \%$ & $20.3 \%$ \\
\hline \multirow{2}{*}{\multicolumn{2}{|c|}{ Total }} & Total & 190 & 602 & 792 \\
\hline & & $\%$ in JobTitle & $100.0 \%$ & $100.0 \%$ & $100.0 \%$ \\
\hline
\end{tabular}

Table 4 indicates clearly that the majority of respondents, over $60 \%$, and even $70 \%$ for chief nurses, find that work interferes with their personal life. These are high percentages, indicating interference or work in personal life which often includes family issues. However, Table 5 shows that respondents are hesitant to indicate that they do not assume their family or personal responsibilities. There 
are about $40 \%$ who disagree and $40 \%$ who agree, another $20 \%$ being neither in agreement or disagreement. Table 6 is however clearer, as it indicates that a small majority indicate they cannot what they want to do in their personal life because of work demands. As was observed in Table 4, there appear to be clear impediments coming from work demands interfering with personal life.

Table 4. Work demands interfere with my personal life.

\begin{tabular}{|c|c|c|c|c|c|}
\hline & & & \multicolumn{2}{|c|}{ JobTitle } & \multirow{2}{*}{ Total } \\
\hline & & & Chief nurse & Nurse & \\
\hline \multirow{12}{*}{ WFC1 } & & Number & 6 & 29 & 35 \\
\hline & Totaly uisagree & $\%$ in JobTitle & $3.2 \%$ & $4.8 \%$ & $4.4 \%$ \\
\hline & \multirow{2}{*}{ Disagree } & Number & 20 & 105 & 125 \\
\hline & & $\%$ in JobTitle & $10.5 \%$ & $17.4 \%$ & $15.8 \%$ \\
\hline & \multirow{2}{*}{$\begin{array}{c}\text { Neither agree nor } \\
\text { disagree }\end{array}$} & Number & 36 & 111 & 147 \\
\hline & & $\%$ in JobTitle & $18.9 \%$ & $18.4 \%$ & $18.6 \%$ \\
\hline & \multirow{2}{*}{ Agree } & Number & 72 & 208 & 280 \\
\hline & & $\%$ in JobTitle & $37.9 \%$ & $34.6 \%$ & $35.4 \%$ \\
\hline & \multirow{2}{*}{ Totally agree } & Number & 56 & 149 & 205 \\
\hline & & $\%$ in JobTitle & $29.5 \%$ & $24.8 \%$ & $25.9 \%$ \\
\hline & \multirow{2}{*}{ Total } & Total & 190 & 602 & 792 \\
\hline & & $\%$ in JobTitle & $100.0 \%$ & $100.0 \%$ & $100.0 \%$ \\
\hline
\end{tabular}

Table 5. My work takes up so much time that it is difficult for me to take on my family-personal responsibilities.

\begin{tabular}{|c|c|c|c|c|c|}
\hline & & & \multicolumn{2}{|c|}{ JobTitle } & \multirow{2}{*}{ Total } \\
\hline & & & Chief nurse & Nurse & \\
\hline \multirow{10}{*}{ WFC2 } & \multirow{2}{*}{ Totally disagree } & Number & 9 & 62 & 71 \\
\hline & & $\%$ in JobTitle & $4.7 \%$ & $10.3 \%$ & $9.0 \%$ \\
\hline & \multirow{2}{*}{ Disagree } & Number & 39 & 179 & 218 \\
\hline & & $\%$ in JobTitle & $20.5 \%$ & $29.7 \%$ & $27.5 \%$ \\
\hline & \multirow{2}{*}{$\begin{array}{c}\text { Neither agree nor } \\
\text { disagree }\end{array}$} & Number & 43 & 128 & 171 \\
\hline & & $\%$ in JobTitle & $22.6 \%$ & $21.3 \%$ & $21.6 \%$ \\
\hline & \multirow{2}{*}{ Agree } & Number & 73 & 151 & 224 \\
\hline & & $\%$ in JobTitle & $38.4 \%$ & $25.1 \%$ & $28.3 \%$ \\
\hline & \multirow{2}{*}{ Totally agree } & Number & 26 & 82 & 108 \\
\hline & & $\%$ in JobTitle & $13.7 \%$ & $13.6 \%$ & $13.6 \%$ \\
\hline \multirow{2}{*}{\multicolumn{2}{|c|}{ Total }} & Total & 190 & 602 & 792 \\
\hline & & $\%$ in JobTitle & $100.0 \%$ & $100.0 \%$ & $100.0 \%$ \\
\hline
\end{tabular}


Table 6. I cannot do what I want in my personal life because of work demands.

\begin{tabular}{|c|c|c|c|c|c|}
\hline & & & \multicolumn{2}{|c|}{ JobTitle } & \multirow{2}{*}{ Total } \\
\hline & & & Chief nurse & Nurse & \\
\hline \multirow{12}{*}{ WFC3 } & & Number & 11 & 70 & 81 \\
\hline & & $\%$ in JobTitle & $5.8 \%$ & $11.6 \%$ & $10.2 \%$ \\
\hline & \multirow{2}{*}{ Disagree } & Number & 45 & 171 & 216 \\
\hline & & $\%$ in JobTitle & $23.7 \%$ & $28.4 \%$ & $27.3 \%$ \\
\hline & \multirow{2}{*}{$\begin{array}{c}\text { Neither agree nor } \\
\text { disagree }\end{array}$} & Number & 45 & 129 & 174 \\
\hline & & $\%$ in JobTitle & $23.7 \%$ & $21.4 \%$ & $22.0 \%$ \\
\hline & \multirow{2}{*}{ Agree } & Number & 60 & 146 & 206 \\
\hline & & $\%$ in JobTitle & $31.6 \%$ & $24.3 \%$ & $26.0 \%$ \\
\hline & \multirow{2}{*}{ Totally agree } & Number & 29 & 86 & 115 \\
\hline & & $\%$ in JobTitle & $15.3 \%$ & $14.3 \%$ & $14.5 \%$ \\
\hline & \multirow{2}{*}{ Total } & Total & 190 & 602 & 792 \\
\hline & & $\%$ in JobTitle & $100.0 \%$ & $100.0 \%$ & $100.0 \%$ \\
\hline
\end{tabular}

Table 7 is closer to Table 5, as again we find that respondents are not a majority to indicate that they cannot take on their family responsibilities because of work, but still a good $40 \%$ indicate this is an issue. In Table 8, a majority indicate that they need to change their plans for personal or family activities because of work, and we can imagine this is the case in particular for all those nurses who have had to do compulsory overtime over the last few years, as this often meant 16 hours of work in one day, with no break in between shifts.

\subsection{Time Available for Work Tasks and Breaks}

Finally, in this section we analyze the issue of lack of time to do the required tasks or to take a break. As Lean management often means imposing limits to the time permitted to do a task, this is an important issue that had come out in the literature and in media or union documents (Parisot, 2014; FIQ, 2011).

Table 9 indicates that a clear majority of respondents, almost three quarters, indicate they agree and totally agree that it has become more difficult to have enough time to do the tasks required by one's work. As we did not want to have responses related only to the pandemic period, we asked the question with reference to a period of 3 years. The conclusion is clear, even more so since the percentage of those who disagree is under $10 \%$.

Table 10 indicates again that a majority consider it difficult to find time to take a break. Only about $15 \%$ disagree on this, so there is clearly an issue with lack of time in nurses' work. As mentioned in literature on Lean Management and in the section above, this management practice tends to impose time limits for doing various tasks, which could work in the Automobile sector, but under- 
standably seems to pose problems in the health and nursing sector in particular. This had been mentioned in interviews a few years ago when Lean started being implemented in some hospitals (Tremblay, 2014a), but seems to have remained an issue, as our data show.

Table 7. Pressure at work makes it difficult for me to take on my family responsibilities.

\begin{tabular}{|c|c|c|c|c|c|}
\hline & & & \multicolumn{2}{|c|}{ JobTitle } & \multirow{2}{*}{ Total } \\
\hline & & & Chief nurse & Nurse & \\
\hline \multirow{12}{*}{ WFC4 } & & Number & 13 & 65 & 78 \\
\hline & & $\%$ in JobTitle & $6.8 \%$ & $10.8 \%$ & $9.8 \%$ \\
\hline & \multirow{2}{*}{ Disagree } & Number & 55 & 179 & 234 \\
\hline & & $\%$ in JobTitle & $28.9 \%$ & $29.7 \%$ & $29.5 \%$ \\
\hline & \multirow{2}{*}{$\begin{array}{c}\text { Neither agree nor } \\
\text { disagree }\end{array}$} & Number & 39 & 122 & 161 \\
\hline & & $\%$ in JobTitle & $20.5 \%$ & $20.3 \%$ & $20.3 \%$ \\
\hline & \multirow{2}{*}{ Agree } & Number & 55 & 162 & 217 \\
\hline & & $\%$ in JobTitle & $28.9 \%$ & $26.9 \%$ & $27.4 \%$ \\
\hline & \multirow{2}{*}{ Totally agree } & Number & 28 & 74 & 102 \\
\hline & & $\%$ in JobTitle & $14.7 \%$ & $12.3 \%$ & $12.9 \%$ \\
\hline & \multirow{2}{*}{ Total } & Total & 190 & 602 & 792 \\
\hline & & $\%$ in JobTitle & $100.0 \%$ & $100.0 \%$ & $100.0 \%$ \\
\hline
\end{tabular}

Table 8. Because of my professional responsibilities, I need to change my planning for family and personal activities.

\begin{tabular}{|c|c|c|c|c|c|}
\hline & & & \multicolumn{2}{|c|}{ JobTitle } & \multirow{2}{*}{ Total } \\
\hline & & & Chief nurse & Nurse & \\
\hline \multirow{12}{*}{ WFC3 } & & Number & 7 & 47 & 54 \\
\hline & & $\%$ in JobTitle & $3.7 \%$ & $7.8 \%$ & $6.8 \%$ \\
\hline & \multirow{2}{*}{ Disagree } & Number & 33 & 132 & 165 \\
\hline & & $\%$ in JobTitle & $17.4 \%$ & $21.9 \%$ & $20.8 \%$ \\
\hline & \multirow{2}{*}{$\begin{array}{c}\text { Neither agree nor } \\
\text { disagree }\end{array}$} & Number & 23 & 90 & 113 \\
\hline & & $\%$ in JobTitle & $12.1 \%$ & $15.0 \%$ & $14.3 \%$ \\
\hline & \multirow{2}{*}{ Agree } & Number & 94 & 222 & 316 \\
\hline & & $\%$ in JobTitle & $49.5 \%$ & $36.9 \%$ & $39.9 \%$ \\
\hline & \multirow{2}{*}{ Totally agree } & Number & 33 & 111 & 144 \\
\hline & & $\%$ in JobTitle & $17.4 \%$ & $18.4 \%$ & $18.2 \%$ \\
\hline & \multirow{2}{*}{ Total } & Total & 190 & 602 & 792 \\
\hline & & $\%$ in JobTitle & $100.0 \%$ & $100.0 \%$ & $100.0 \%$ \\
\hline
\end{tabular}


Table 9. Over the last 3 years, it has become more difficult to have enough time to do the required tasks.

\begin{tabular}{|c|c|c|c|c|c|}
\hline & & & \multicolumn{2}{|c|}{ JobTitle } & \multirow{2}{*}{ Total } \\
\hline & & & Chief nurse & Nurse & \\
\hline \multirow{12}{*}{ JDP1 } & & Number & 0 & 8 & 8 \\
\hline & Aveniy uivagtes & $\%$ in JobTitle & $0.0 \%$ & $1.3 \%$ & $1.0 \%$ \\
\hline & \multirow{2}{*}{ Disagree } & Number & 8 & 60 & 68 \\
\hline & & $\%$ in JobTitle & $4.2 \%$ & $10.0 \%$ & $8.6 \%$ \\
\hline & \multirow{2}{*}{$\begin{array}{c}\text { Neither agree nor } \\
\text { disagree }\end{array}$} & Number & 25 & 115 & 140 \\
\hline & & $\%$ in JobTitle & $13.2 \%$ & $19.1 \%$ & $17.7 \%$ \\
\hline & \multirow{2}{*}{ Agree } & Number & 86 & 221 & 307 \\
\hline & & $\%$ in JobTitle & $45.3 \%$ & $36.7 \%$ & $38.8 \%$ \\
\hline & \multirow{2}{*}{ Totally agree } & Number & 71 & 198 & 269 \\
\hline & & $\%$ in JobTitle & $37.4 \%$ & $32.9 \%$ & $34.0 \%$ \\
\hline & \multirow{2}{*}{ Total } & Total & 190 & 602 & 792 \\
\hline & & $\%$ in JobTitle & $100.0 \%$ & $100.0 \%$ & $100.0 \%$ \\
\hline
\end{tabular}

Table 10. Over the last 3 years, it has become more difficult to find time to take a break.

\begin{tabular}{|c|c|c|c|c|c|}
\hline & & & \multicolumn{2}{|c|}{ JobTitle } & \multirow{2}{*}{ Total } \\
\hline & & & Chief nurse & Nurse & \\
\hline \multirow{10}{*}{ JDP2 } & \multirow{2}{*}{ Totally disagree } & Number & 3 & 12 & 15 \\
\hline & & $\%$ in JobTitle & $1.6 \%$ & $2.0 \%$ & $1.9 \%$ \\
\hline & \multirow{2}{*}{ Disagree } & Number & 12 & 100 & 112 \\
\hline & & $\%$ in JobTitle & $6.3 \%$ & $16.6 \%$ & $14.1 \%$ \\
\hline & \multirow{2}{*}{$\begin{array}{c}\text { Neither agree nor } \\
\text { disagree }\end{array}$} & Number & 51 & 144 & 195 \\
\hline & & $\%$ in JobTitle & $26.8 \%$ & $23.9 \%$ & $24.6 \%$ \\
\hline & \multirow{2}{*}{ Agree } & Number & 76 & 205 & 281 \\
\hline & & $\%$ in JobTitle & $40.0 \%$ & $34.1 \%$ & $35.5 \%$ \\
\hline & \multirow{2}{*}{ Totally agree } & Number & 48 & 141 & 189 \\
\hline & & $\%$ in JobTitle & $25.3 \%$ & $23.4 \%$ & $23.9 \%$ \\
\hline & \multirow{2}{*}{ Total } & Total & 190 & 602 & 792 \\
\hline & & $\%$ in JobTitle & $100.0 \%$ & $100.0 \%$ & $100.0 \%$ \\
\hline
\end{tabular}

\section{Discussion}

As the data showed above, in section 3.1, respondents appear to be able to exercise their judgment, and take decisions in their workplace. Thus, while some literature and media reports indicated that nurses wanted more autonomy and professionalization in their work environment, our respondents here do not indicate this as a major source of difficulty or annoyance. 
In section 3.2, as concerns work-family or work-life interference, we find more mixed results, although work-family interference seems often dominant. While there are often one fifth of respondents who are unsure (neither agree nor disagree), it appears that work does interfere with family activities, and responsibilities, although most respondents consider they find a way to take on their responsibilities, or at least respond that they do so (see Table 5 and Table 7). It might indeed be difficult to admit to not assuming family responsibilities, and oftentimes just difficult not to take them on. However, Table 4, Table 6 and Table 8 show that respondents find that work interferes with their personal life, that they cannot do what they want to do in their personal life because of work demands and finally that they need to change their plans for personal or family activities because of work. On this last point, it is surely is the case for all those nurses who have had to do compulsory overtime over the last years; as this often means working 16 hours in one day instead of an 8 hour shift, with no break in between shifts, one can imagine how this can have an impact on personal and family plans. This is in line with previous qualitative results on work organization in the nursing sector (Tremblay, 2014a).

Section 3.3 presents some elements which can be related to Lean management. Indeed this management practice often implies imposing time limits to do a given task, and over the years, in interviews with nurses (Tremblay, 2014a) as well as in union documents (FIQ, 2011), this appeared to be an important issue. We thus wanted to see if this still was an issue today, a few years after the introduction of Lean Management in many hospitals.

Research results indicates that almost three quarters of respondents indicate they agree that it has become more difficult to have enough time to do the tasks required by the work (Table 9 ).

Research results also indicate that for a majority it is difficult to find time to take a break (Table 10). Only about $15 \%$ of respondents disagree on this, so there is clearly a problem with lack of time for nurses to do their work, and to do it correctly, with the quality of care they would want to offer. Lean Management practices impose time limits for doing various tasks, and this seems to pose problems in the health and nursing sector in particular, as health workers deal with humans and not with objects, and these humans are also aging and oftentimes have various conditions on top of the one for which they are treated (for ex. diabetes, obesity, Alzeimer, etc.).

\section{Conclusion}

Some recommendations can be drawn from this research. First, in order to attain the objective of attracting and retaining nurses, it would be important to carefully address the issue of work-life and work-family interference and find solutions to make it possible for nurses and other health workers to have a personal and family life and activities. Second, it would be important for health organizations to think of work reorganization, and review the application of Lean Management in health organizations, especially as concerns time issues, since 
the application of Lean for nurses, who work with patients, is quite different from its application in the car production industry, where workers essentially have to deal with objects.

It could be useful to go back to the origins of the concept, and the Japanese mode of innovation management (Tremblay \& Rolland, 2019) and put the workers (here the nurses) at the center of the work process. This would mean asking them for ideas on how to solve problems, how to maintain performance while giving the quality of care they aspire to give, in other words giving them a voice in the process, and the ways to improve their work as well as patient care.

As in all research, there are limits to the analysis presented here. First, one can never consider that the respondents are perfectly representative of the population of nurses, even if the emails were sent out to a random selection of registered nurses. Second, while the response rate is between one quarter and one third of all emails sent out, it is difficult to calculate a precise response rate, as we do not know what number of persons really received and read the email, as many do not use their professional email. Also, the nurses' association could not guarantee that all names and emails referred to nurses who were still active in the profession and not retired. In fact, we did come upon a few persons who wrote to us asking why we had solicited their participation as they were in fact retired. This reduces the number of potential respondents. We are also confronted with the limits of quantitative data in that we do not have explanations for the answers, for example between differences of perception on the impact of work on work-family interface, and on family responsibilities.

However, as mentioned above, we are now doing interviews to complete the quantitative data. Indeed, these interviews will help to complete the quantitative results and to gain a better understanding of other issues covered in the research. The qualitative data will surely complement the quantitative data collected and analysed here, but the data presented here on the impacts of work on work-life interface (section 3.2) and on lack of time (section 3.3) are clearly very interesting and already offer avenues for recommendations to hospitals and health authorities as concerns elements of dissatisfaction which could be corrected in order to contribute to better levels of attraction and retention of nurses. In fact, it is possible that many of the results could be applicable in other sectors as well, as work-family challenges, time management and lean work organization are issues in other sectors and professions.

\section{Acknowledgements}

Authors want to acknowledge financial contribution of the Social Sciences Research Council of Canada.

\section{Conflicts of Interest}

The author declares no conflicts of interest regarding the publication of this paper. 


\section{References}

Allen, T. D. (2012). The Work-Family Interface. In S. W. J. Kozlowski (Ed.), The Oxford Handbook of Organizational Psychology (pp. 1163-1198). Oxford University Press. https://doi.org/10.1093/oxfordhb/9780199928286.013.0034

Bélanger, A., \& Marois, G. (2015). Vieillissement de la population dans la région métropolitaine de Montréal: Perspectives démographiques locale. Cahiers québécois de démographie, 44, 129. https://doi.org/10.7202/1032151ar

Belorgey, N. (2011). Réduire le temps d'attente et de passage aux urgences. Une entreprise de "réforme" d'un service public et ces effets sociaux. Actes de la Recherche en Sciences Sociales, 4, 16-33. https://doi.org/10.3917/arss.189.0016

Boudou-Laforce, E. (2014). La méthode Lean, ou comment déshumaniser les services de santé au Québec.

https://quebec.huffingtonpost.ca/etienne-boudou-laforce/methode-lean-sante b 37618 79.html

Boudou-Laforce, E. (2014). La méthode Lean, ou comment déshumaniser les services de santé au Québec.

https://quebec.huffingtonpost.ca/etienne-boudou-laforce/methode-lean-sante b 37618 79.html

Bourbonnais, R., Malenfant, R., Viens, C., Vézina, M., \& Côté, N. (2000). Le travail infirmier sous tension. Une approche compréhensive du travail infirmier en période de transition. Rapport de recherche, Équipe de recherche RIPOST, Université Laval et Direction de la santé publique de Québec.

Bouville, G., \& Trempe, C. (2015). La mise en place du lean management: Un bouleversement de l'univers hospitalier? Performance et innovation dans les établissements de santé (pp. 253-266). https://doi.org/10.3917/dunod.fermo.2015.01.0253

Braunstein-Bercovitz, H. (2013). A Multidimensional Mediating Model of Perceived Resource Gain, Work-Family Conflict Sources, and Burnout. International Journal of Stress Management, 20, 95-115. https://psycnet.apa.org/record/2013-18919-001 https://doi.org/10.1037/a0032948

Côté, N. (2016). Understanding Turnover as a Lifecycle Process: The Case of Young Nurses. Relations Industrielles/Industrial Relation, 71, 203-223. https://doi.org/10.7202/1036607ar

Côté, N., Bourbonnais, R., Bolduc, N., Duchesne, A., Jauvin, N., \& Lafond, M. (2014). La fidélisation des jeunes infirmières et infirmières auxiliaires en CSSS. Rapport de recherche, CSSS de la Vieille-Capitale, équipe RIPOST, Québec. https://www.erudit.org/en/journals/ri/1900-v1-n1-ri02537/1036607ar

Eby, L. T., Maher, C. P., \& Butts, M. M. (2010). The Intersection of Work and Family Life: The Role of Affect. Annual Review of Psychology, 61, 599-622. https://doi.org/10.1146/annurev.psych.093008.100422

Farges, G., \& Tremblay, D.-G. (2016). Temps sociaux et fins de carrière des enseignants; continuité et recomposition dans les inégalités hommes-femmes. Cahiers du Cirtes, 313-328.

Fiksenbaum, L. M. (2014). Supportive Work-Family Environments: Implications for Work-Family Conflict and Well-Being. The International Journal of Human Resource Management, 25, 653-672. https://doi.org/10.1080/09585192.2013.796314

FIQ (Fédération des infirmières du Québec) (2011). Des modèles de gestion à connaître: Lean, Six Sigma et Lean Six Sigma. FIQ.

http://www.fiqsante.qc.ca/wp-content/uploads/2017/02/2013-fascicule-tot-6-lean-fr.pd 
$\underline{\text { f?download }=1}$

Goh, Z., Ilies, R., \& Wilson, K. S. (2015). Supportive Supervisors Improve Employees' Daily Lives: The Role Supervisors Play in the Impact of Daily Workload on Life Satisfaction via Work-Family Conflict. Journal of Vocational Behavior, 89, 65-73.

https://doi.org/10.1016/j.jvb.2015.04.009

Hammer, L. B., Kossek, E. E., Yragui, N. L., Bodner, T. E., \& Hanson, G. C. (2009). Development and Validation of a Multidimensional Measure of Family Supportive Supervisor Behaviors (FSSB). Journal of Management, 35, 837-856.

https://doi.org/10.1177/0149206308328510

Jancarik, A.-S., \& et Vermette, L. (2013). Recension des écrits sur des méthodes de types Lean (130 p). Agence de la santé et des services sociaux de la Montérégie.

Kossek, E. E., Pichler, S., Bodner, T., \& Hammer, L. B. (2011). Workplace Social Support and Work-Family Conflict: A Meta-Analysis Clarifying the Influence of General and Work-Family-Specific Supervisor and Organizational Support. Personnel Psychology, 64, 289-313. https://doi.org/10.1111/j.1744-6570.2011.01211.x

Lazzari Dodeler, N., \& Tremblay, D.-G. (2016). La conciliation emploi-famille/vie personnelle chez les infirmières en France et au Québec: Une entrée par le groupe professionnel. Revue Interventions économiques, 54.

http://interventionseconomiques.revues.org/2700

https://doi.org/10.4000/interventionseconomiques.2700

Malenfant, R., LaRue, A., Jetté, M., \& Côté, N. (2010). L'autonomie prescrite et la domination au travail. Les contours d'une épreuve. Dans R. Malenfant \& G. Bellemare 4 (dir.), La domination au travail. Des conceptions totalisantes à la diversification des formes de domination. Québec, Presses de l’Université du Québec, 53-74.

Mansour, S., \& Tremblay, D. G. (2018a). Blended Work and Opportunities for Knowledge Sharing: Human Resource Management Practices to Increase Innovative Work Behaviour and Life Satisfaction of Bridge Workers. International Journal of Knowledge-Based Development, 9, 441-459.

https://doi.org/10.1504/IJKBD.2018.10012273

https://www.inderscienceonline.com/doi/pdf/10.1504/IJKBD.2018.096419

Mansour, S., \& Tremblay, D. G. (2018b). Mediating Role of Work Engagement between Psychosocial Safety Climate and Organizational Citizenship Behaviors: A Study in the Nursing and Health Sector in Quebec. International Journal of Human Resource Development and Management, 18, 51-71. https://doi.org/10.1504/IJHRDM.2018.10013646

Mansour, S., \& Tremblay, D. G. (2018c). Work-Family Conflict/Family-Work Conflict, Job Stress, Burnout and Intention to Leave in the Hotel Industry in Quebec (Canada): Moderating Role of Need for Family Friendly Practices as "Resource Passageways". The International Journal of Human Resource Management, 29, 1-33. https://doi.org/10.1080/09585192.2016.1239216

Mansour, S., \& Tremblay, D. G. (2018d). Psychosocial Safety Climate as Resource Passageways to Alleviate Work-Family Conflict: A Study in the Health Sector in Quebec. Personnel Review, 47, 474-493. https://doi.org/10.1108/PR-10-2016-0281

Mansour, S., \& Tremblay, D. G. (2019). What Strategy of Human Resource Management to Retain Older Workers? International Journal of Manpower, 40, 135-153. https://doi.org/10.1108/IJM-07-2017-0170

Nogues, S., \& Tremblay, D.-G. (2019). Managing Work-Nonwork Boundaries in Atypical Working Patterns: Evidence from Flight Attendants in Canada and Germany. Employee Responsibilities and Rights Journal, 31, 197-221. https://rdcu.be/bMTcD 
https://doi.org/10.1007/s10672-019-09338-7

Nsaful, A., Sheng, J., \& Nii Martey, E. (2021). Gender as a Moderator between Work-Family Conflict and Job Satisfaction of Medical Doctors: The Case of Ghana. Journal of Human Resource and Sustainability Studies, 9, 193-211. https://doi.org/10.4236/jhrss.2021.92013

Oyetunde, M., \& Ayeni, O. (2014). Exploring Factors Influencing Recruitment and Retention of Nurses in Lagos State, Nigeria within Year 2008 and 2012. Open Journal of Nursing, 4, 590-601. https://doi.org/10.4236/ojn.2014.48062

Parisot, F. (2014). Dérives du Lean; pourquoi la méthode s'est écartée des principes originaux. L'Usine nouvelle.

https://www.usinenouvelle.com/article/derives-du-lean-pourquoi-la-methode-s-est-eca rtee-des-principes-originaux.N293559

Poelmans, S. A. Y., Greenhaus, J. H., \& Maestro, M. L. H. (2013). Expanding the Boundaries of Work-Family Research: A Vision for the Future. Palgrave. https://doi.org/10.1057/9781137006004

Tremblay, D.-G. (2008). Work-Family Policies: The Québec and Canadian Contexts. In J. Martin (Ed.), Work and Family Balance; Economic and Social Benefits in a Time of Labour Force Shortages (pp. 65-73). Labour Dept.

Tremblay, D.-G. (2009). Quebec's Policies for Work-Family Balance: A Model for Canada? In M. Cohen, \& J. Pulkingham (Eds.), Public Policy for Women. The State, Income Security and Labour Market Issues (pp. 271-290). University of Toronto Press. https://doi.org/10.3138/9781442688889-014

Tremblay, D.-G. (2012). Articuler emploi et famille: Le rôle du soutien organisationnel au coeur de trois professions (infirmières, travailleuses sociales et policiers) (284 p.). Presses de l'université du Québec. https://doi.org/10.2307/j.ctv18ph9cn

Tremblay, D.-G. (2014a). Infirmière: Vocation, engagement et parcours de vie (153 p.). Éditions du Remue-ménage.

Tremblay, D.-G. (2014b) Quebec's Policies for Work-Family Balance: A Model for Canada? In B. Fox (Ed.), Family Patterns, Gender Relations (4th ed., pp. 541-554). Oxford University Press.

Tremblay, D.-G. (2019). Conciliation emploi-famille et temps sociaux. Presses de l'université du Québec. https://doi.org/10.2307/j.ctv10qqxm1

Tremblay, D.-G., \& Rolland, D. (2019). Gestion des ressources humaines; typologies et comparaisons internationales. Presses de l'université du Québec. https://doi.org/10.2307/j.ctv1n35drf

Waring, J. J., \& Bishop, S. (2010). "Water Cooler” Learning: Knowledge Sharing at the Clinical "Backstage" and Its Contribution to Patient Safety. Journal of Health Organization and Management, 24, 325-342. https://doi.org/10.1108/14777261011064968 